\title{
Aerosol Fast Flow Reactor for Laboratory Studies of New Particle Formation
}

\author{
M. J. Ezell, H. Chen, K. D. Arquero and B. J. Finlayson-Pitts* \\ Department of Chemistry \\ University of California Irvine \\ Irvine, CA 92697-2025 \\ Revision for: \\ Journal of Aerosol Science
}

August 27, 2014

*Author to whom correspondence should be addressed. Phone (949) 824-7670; FAX (949) 8242420; email bjfinlay@uci.edu; 


\begin{abstract}
Understanding the fundamental mechanisms of new particle formation and growth (NPFG) is critical to the development of accurate quantitative models of atmospheric particulate matter. Challenges to elucidating the chemistry of these processes include accessing a variety of well-controlled experimental conditions approaching the point of new particle formation, and having an inexpensive system which can be reproducibly maintained with low levels of contaminants from previous runs and other sources. We describe here the design and characterization of a flow tube reactor for such studies, and its initial application to NPFG from the reaction of the gas phase precursors methanesulfonic acid and trimethylamine in the absence or presence of added water vapor. Insights into some of the fundamental processes involved in NPFG that could not be obtained in earlier studies using our large volume, slow flow system are described.
\end{abstract}




\section{INTRODUCTION}

Airborne particles are of great interest due to their impacts on visibility (Hinds, 1999), human health (Heal et al., 2012; Mauderly \& Chow, 2008; Pope III \& Dockery, 2006) and climate (Finlayson-Pitts \& Pitts, 2000; Hinds, 1999; IPCC, 2013; Pandis \& Seinfeld, 2006). While there are direct emissions of particles, a large component is formed from reactions of precursor gases to form low volatility products (Donahue et al., 2009; Hallquist et al., 2009; Holzinger et al., 2007; Pöschl, 2005; R. Y. Zhang et al., 2012) that either form new particles or add to existing ones to grow them to sizes of $\sim 100$ $\mathrm{nm}$ where they scatter light and act as cloud condensation and ice nuclei. The nature of these precursors and the reactions are not well established. It is known that $\mathrm{SO}_{2}$ formed from the combustion of fossil fuels as well as the oxidation products of organosulfur compounds are converted in air to $\mathrm{H}_{2} \mathrm{SO}_{4}$ which, in the presence of water, ammonia and/or amines, forms particles (Chen et al., 2012; Kuang et al., 2008; McMurry, 1980; Riipinen et al., 2007; R. Y. Zhang, et al., 2012; Zollner et al., 2012). However, the fundamental kinetics and mechanisms involved have not been fully elucidated. Furthermore, there are other potential precursors such as methanesulfonic acid (MSA, $\mathrm{CH}_{3} \mathrm{SO}_{3} \mathrm{H}$ ) (Dawson et al., 2012) formed simultaneously with $\mathrm{H}_{2} \mathrm{SO}_{4}$ in the organosulfur oxidations, as well as higher molecular mass organic products formed from the oxidation of volatile organic compounds (VOC) in air (Ehn et al., 2014; Lee \& Kamens, 2005; Zhao et al., 2013). Finally, it is not known if there are synergistic interactions of organics with sulfuric acid/or MSA, to enhance or inhibit new particle formation and growth (Dommen et al., 2013; Kulmala et al., 2013; R. Y. Zhang, et al., 2012). A full understanding of such issues on a molecular basis is central to the development of accurate models of particle formation and their growth in air. 
Probing new particle formation and growth in well-controlled laboratory systems is challenging. As such, a variety of experimental approaches is needed to cover particle formation and growth from the earliest stages (with reactions times of seconds) up to growth to hundreds of nanometers with much longer reaction times from several minutes to hours. For the latter, we have previously described a large volume, slow flow system (Ezell et al., 2010) with residence times from 4 to 120 minutes. Here we describe a fast flow system with variable residence times in the flow tube from 0.2 to 30 seconds.

Ideally, one would like to study these reactions at sufficiently short reaction times to follow the earliest stages of particle formation under conditions free of contaminants. The latter is especially difficult, particularly with some chamber surfaces such as Teflon that take up and release species, often reversibly (Matsunaga \& Ziemann, 2010; Zhang et al., 2014). This may not be a significant problem if the concentrations of species released from the chamber walls are small relative to the reactant concentrations, but it limits how far the precursor concentrations can be lowered without potentially risking such interferences. One approach to minimizing these problems is the use of reaction chambers made of non-porous, relatively unreactive materials such as glass that can be easily cleaned on a regular basis, and that also allow access to relatively short reaction times.

We describe here the design and characterization of a flow system that meets these criteria. In addition, we present some initial results on the formation of particles from the reaction of MSA with trimethylamine (TMA, $\left.\left(\mathrm{CH}_{3}\right)_{3} \mathrm{~N}\right)$ that demonstrate the utility of this approach.

\section{AEROSOL FLOW SYSTEM DESIGN}


The aerosol fast-flow system (Fig. 1) designed to cover relatively short reaction times from 0.2 to 30 seconds (not including sampling time; see below) was fabricated from borosilicate glass. The major section has an inside diameter of $7.6 \mathrm{~cm}$ and a total length of $1.3 \mathrm{~m}$ with a water-jacketed section 1.1 $\mathrm{m}$ long. At either end of this main section are two end-caps mated to the central tube with clamps and sealed by O-rings.

The upstream end cap is $10.5 \mathrm{~cm}$ in length and holds two perforated hollow glass rings that serve as fixed inlets for reactants and dry or humidified air. These $6.7 \mathrm{~cm}$ o.d. rings are both formed from one centimeter o.d. glass tubing and are perforated by thirty-six, evenly spaced $0.05 \mathrm{~cm}$ holes to disperse air and reactant gases (see Fig. 1, inlets A and B). The upstream cap also secures and guides two concentric glass tubes that serve as movable inlets for either reactants and/or dry or humidified air, with an overall length of $78 \mathrm{~cm}$. Each of these concentric tubes terminates in six $0.5 \mathrm{~cm}$ diameter glass 'spokes' that efficiently disperse reactant and mixing air in the radial direction through four 0.05 $\mathrm{cm}$ holes in each of the six spokes. The set of spokes that is furthest downstream relative to the overall flow (inlet D, Fig. 1), serves as the inlet for one of the reactant gases and has small holes directed upstream towards the other set of spokes (inlet C, Fig. 1), $1.0 \mathrm{~cm}$ away, which carries mixing air. The perforations in inlet $\mathrm{C}$ are directed so as to transect the overall flow and serve to provide a turbulent regime for efficient mixing of reactant gases coming from the inlet $\mathrm{D}$ as well as species from the upstream fixed rings.

The smaller end cap at the downstream end of the flow tube is $6.5 \mathrm{~cm}$ in length and guides a stainlesssteel $1 / 4$ inch sampling tube that is $76 \mathrm{~cm}$ in length and is aligned along the major axis of the flow tube. This end cap also has a $1 / 2$ inch tube to vent the majority of the gas and particle flow. Both end caps 
also have a sealable $1 / 2$ inch port to hold a relative humidity/temperature probe. These large removable caps facilitate cleaning of the flow tube in about an hour. Finally, the main body of the flow tube also has three $1 / 4$ inch glass ports for additional sampling or inlets, one at each end and a third located midway along the length of the water-jacketed portion of the flow tube. The flow tube total volume is $5.9 \mathrm{~L}$ and total surface area is $3.11 \times 10^{3} \mathrm{~cm}^{2}$, resulting in a surface to volume ratio of $0.53 \mathrm{~cm}^{-1}$.

Sampling of particles or gases from the flow tube is accomplished using the movable $1 / 4$ inch stainless steel sampling tube. Additionally, filters can be fitted to either end of the sampling tube for collection of particles and/or gases for off-line analysis.

\section{FLOW PARAMETERS}

Fluid dynamics for both gases and suspended particles is characterized by three dimensionless parameters: the Reynolds number, $R e$, the Stokes number, Stk, and the Richardson number, $R i$.

\subsection{Reynolds Number $(R e)$}

The Reynolds number is the ratio of inertial to viscous forces, and provides a measure of whether the flow is laminar or turbulent (Hinds, 1999). For flow in a cylinder, the flow Reynolds number is given by $R e=$ $\rho V L / \eta$ where $\rho$ and $\eta$ are the density $\left(1.19 \mathrm{~kg} \mathrm{~m}^{-3}\right)$ and dynamic viscosity $\left(1.84 \times 10^{-7} \mathrm{~Pa} \mathrm{~s}\right)$ of air at $23{ }^{\circ} \mathrm{C}$, $V$ the mean flow velocity and $L$ is a characteristic length, in this case the diameter of the flow tube. Typical bulk flows in this system range from 6 to $17 \mathrm{~L} \mathrm{~min}^{-1}$ and flow speeds from 2.9 to $7.2 \mathrm{~cm} \mathrm{~s}^{-1}$, determined from residence time measurements (Section 4.2). The corresponding flow Reynolds numbers range from 142 to 353 respectively. These low numbers indicate laminar flow for this system since they 
are much less than 2000 to 2300, the upper limit for laminar flow through a pipe (Hinds, 1999; Holman, 2002).

For flow around particles, the particle Reynolds number is defined similarly but $L$ is particle diameter, $d_{p}$ (Hinds, 1999). Additionally, for particles with an aerodynamic diameter of $10 \mathrm{~nm}$ (typical of the largest particles sampled in experiments described below) and at the highest total flow in our system $\left(17 \mathrm{~L} \mathrm{~min}^{-1}\right.$, corresponding speed $=0.072 \mathrm{~m} \mathrm{~s}^{-1}$ ), the particle Reynolds number is only 0.00005 . In the sampling line, the highest sample rate is $1.5 \mathrm{~L} \mathrm{~min}^{-1}$ (speed $=1.3 \mathrm{~m} \mathrm{~s}^{-1}$ ) and the particle Reynolds number is again small, 0.0009. In short, either in the flow tube or in the sampling line the particle $R e<<1$, indicating that particle motion is also in the laminar region and particle motion will follow Stokes law (Section 3.2) (Hinds, 1999).

Notwithstanding the low flow Reynolds number that characterizes flow in this system, turbulence is expected near the spoke and ring inlets where the speed of gases exiting the inlets is considerably higher than in the flow tube (Khalizov et al., 2006b). As described in Section 2, the spoked inlets were designed to introduce turbulent mixing near the spokes since some turbulence is beneficial to ensure that reactants mix completely and that particles, once formed, are distributed uniformly throughout the flow tube cross section (Khalizov, et al., 2006b). We present below visual evidence (Section 4.1) that such turbulence quickly transitions to laminar or near-laminar flow about 7 to $10 \mathrm{~cm}$ downstream of the spoke inlets. In agreement with our visual observation, Bernard et al. (Bernard et al., 2012) found in a flow system similar to ours a "mixing zone" that extended just a few centimeters downstream of their movable inlet. Since they operated their system with a gas velocity about one-fifth of ours, a turbulent region of 7 to $10 \mathrm{~cm}$ is reasonable. 


\subsection{Stokes Number (Stk)}

The Stokes number is the ratio of the stopping distance $S$ of a particle to a characteristic dimension, $L$. If the Stokes number is less than 0.01, particles in flowing air will have curvilinear motion and follow precisely gas stream lines as the air passes around an obstacle or converges as is the case when an air/particle mixture is sampled by the $1 / 4$ inch sampling tube. The stopping distance is calculated by $S=U_{0} \rho_{p} d_{p}^{2} C_{c} / 18 \eta$ where $U_{0}$ is the undisturbed fluid velocity, $\rho_{p}$ the particle density, $d_{p}$ the particle diameter, and $C_{c}$ the unitless Cunningham slip correction factor (Hinds, 1999; Seinfeld \& Pandis, 2006). The stopping distance for a particle with a $10 \mathrm{~nm}$ aerodynamic diameter at the velocity of $7.2 \mathrm{~cm} \mathrm{~s}^{-1}$ (determined from residence time measurements at the highest flow of $17 \mathrm{~L} \mathrm{~min}^{-1}$ ) is only $S=5 \times 10^{-8} \mathrm{~cm}$. Taking $L$ equal to the inside diameter $(0.49 \mathrm{~cm})$ of the sampling tube, $S t k=1 \times 10^{-7}$. This near zero value is important for sampling that is not isokinetic. The isokinetic condition requires the gas velocity in the sampling tube, $U$ equal the free-stream velocity, $U_{0}$ and ensures that $C$, the concentration of particles just entering the sampling tube is equal to $C_{0}$, the concentration of particles in the undisturbed flow. In this system at the highest flow of $17 \mathrm{~L} \mathrm{~min}^{-1}$ and a sampling rate of $1.5 \mathrm{~L} \mathrm{~min}^{-1}, U / U_{0} \approx 18$. When $U$ does not equal $U_{0}$, the ratio of these concentrations depends on the Stokes number and is given by an empirical equation (Belyaev \& Levin, 1974):

$$
\frac{C}{C_{0}}=1+\left(\frac{U_{0}}{U}-1\right)\left(1-\frac{1}{1+\left(2+0.62\left(\frac{U}{U_{0}}\right)\right) S t k}\right)
$$

Thus, despite operating the system far from conditions in which $U=U_{0}$, the near zero value of the Stokes number ensures that, for our system at our operating conditions, $C / C_{0}=1$.

\subsection{Richardson number (Ri)}


The Richardson number, $R i=(g \beta \Delta \mathrm{TL}) / \mathrm{U}^{2}$, quantifies the ratio of natural convection (due to a temperature gradient) to forced convection (due to the bulk gas flow), where $\Delta T$ is a temperature difference, $g$ is the acceleration due to gravity, $\beta$ is the thermal expansion coefficient of air $\left(3.39 \times 10^{-3} \mathrm{~K}^{-1}\right.$ at $\left.23^{\circ} \mathrm{C}\right), L$ a characteristic length such as the flow tube radius and $U$ the free-stream velocity. When $R i<<1$, forced convection dominates and when $R i \gg>1$, natural convection dominates, while intermediate values of $R i$ reflect a combination (Incropera \& DeWitt, 2002; Khalizov et al., 2006a). Determination of which regime characterizes our system requires measurement of $\Delta T$ and is described below.

As shown in Figure 1, the flow tube is water-jacketed to provide a range of temperatures suitable for kinetic studies. A circulating temperature bath (Fisher Scientific, Model 9110) was used to warm or cool the flow tube as well as flows of diluent and reactant gases just before entering the flow tube inlets. The latter was achieved by passing the gas flows through separate copper coils immersed in the temperature bath that also heated the flow tube. Additionally, the upstream end cap as well as the un-jacketed end of the flow tube were warmed with heating tape adjusted so that the temperature was within one Kelvin of the water-bath temperature.

If the bulk flow of gas and particles does not quickly reach thermal equilibrium, a substantial temperature gradient, $\Delta T$, may exist across the flow tube cross section, and this may result in natural convection, possibly forming turbulent recirculation zones despite the low Reynolds number that indicates laminar flow.

To determine the regime in which this system operates, temperature measurements were made radially across the flow tube as the temperature of the circulating water bath was increased from $5^{\circ} \mathrm{C}$ to $70^{\circ} \mathrm{C}$. Midway 
along the flow tube length, a thermocouple was inserted into the fixed $1 / 4$ inch port (see Fig. 1) and the radial temperature measured at three locations: (1) the flow tube axis, $r=0$; (2) at $r=1.9 \mathrm{~cm}$; and (3) at the flow tube inner wall, $\mathrm{r}=3.8 \mathrm{~cm}$. At the elevated temperatures $\left(50\right.$ and $\left.70^{\circ} \mathrm{C}\right)$ used in the kinetic study described in Section 4.3, the largest measured radial $\Delta T$ over total flows of 6,11 , or $17 \mathrm{~L} \mathrm{~min}^{-1}$ was $\leq 0.4^{\circ} \mathrm{C}$ at a bath temperature of $50^{\circ} \mathrm{C}$ and $\leq 0.9^{\circ} \mathrm{C}$ at $70^{\circ} \mathrm{C}$. The corresponding Richardson numbers were $\leq 0.1$ and $\leq 0.3$ at $50^{\circ} \mathrm{C}$ and $70^{\circ} \mathrm{C}$ respectively. These values are clearly low and indicate that recirculation zones due to natural convection are not a factor in this system.

\section{EXPERIMENTAL CHARACTERIZATION OF GAS AND PARTICLE FLOWS}

\subsection{Visual Characterization}

Visual characterization of gas flow was easily achieved by the addition of a small flow of nitric oxide (Praxair, 99.5\%, $0.5 \mathrm{~L} \mathrm{~min}^{-1}$ ) introduced in inlet spokes $\mathrm{D}$ of the glass movable inlet along with flows of air through spokes $\mathrm{C}\left(2.0 \mathrm{~L} \mathrm{~min}^{-1}\right.$, ring $\mathrm{B}\left(1.5 \mathrm{~L} \mathrm{~min}^{-1}\right)$ and ring $\mathrm{A}\left(7.0 \mathrm{~L} \mathrm{~min}{ }^{-1}\right)$, for a total flow of $11 \mathrm{~L} \mathrm{~min}^{-1}$. In all experiments, the air supply to the system was compressed air purified by passing through an FTIR purge gas generator (Parker Balston Model 75-62), ZAG Carbon/Alumina Media (Perma Pure LLC) and an inline 0.1 micron filter (DIF-N70, Headline Filters). Hereafter, air flows purified in this manner will be referred to as clean air. All flows between sources and flow tube passed through $1 / 4$ or $3 / 8$ inch Teflon tubing. Separate flow controllers (either Alicat MC-series or MKS, Alta series) metered flows of clean air into the inlet rings and spokes.

Figure 2 shows a snapshot of the $\mathrm{NO}_{2}$ formed as the $\mathrm{NO}$ gas is mixed and reacts with oxygen in the air flow. The shot was taken about midway along the length of the flow tube as seen by the fixed port at the bottom (also see Fig. 1). The movable stainless steel sampling tube is seen at the left (and was sampling at 
1.5 $\mathrm{L} \mathrm{min}^{-1}$ ) and the concentric movable spokes on the right. The distance between the sample line and spokes $\mathrm{D}$ is $3.5 \mathrm{~cm}$. The photo captures what was typically seen under these conditions of NO and total air flow; namely a fairly sharp and persistent boundary separating the colorless NO flow entering the flow of air moving past the downstream spokes and the orange-brown $\mathrm{NO}_{2}$ gas formed as the $\mathrm{NO}$ reacts with oxygen in the air supply. The sharpest boundary was obtained when the flow of the NO through the inlet

spokes D was under $1 \mathrm{~L} \mathrm{~min}^{-1}$ and the flow of air through the inlet spokes $\mathrm{C}$ was at least $1.5 \mathrm{~L} \mathrm{~min}^{-1}$. There was no observable change when flow of air through the upstream rings A and B was either increased or decreased and the flow appeared uniform except for some turbulence observed up to $\sim 7 \mathrm{~cm}$ downstream of the spokes.

\subsection{Residence Times}

The strong visible light absorption by $\mathrm{NO}_{2}$ provided a convenient method to determine residence times as a function of total flow and distance, $\Delta \mathrm{L}$, between the sampling tube entrance and the inlet spokes $\mathrm{D}$ (see Fig. 1). In these measurements, a total flow of $6.0 \mathrm{~L} \mathrm{~min}^{-1}$ was obtained as follows: $3.0 \mathrm{~L} \mathrm{~min}^{-1}$ of air equally divided between the two upstream inlet rings $\mathrm{A}$ and $\mathrm{B}, 2.0 \mathrm{~L} \mathrm{~min}^{-1}$ of air through spokes $\mathrm{C}$, and $1.0 \mathrm{~L} \mathrm{~min}-1$ of air through spokes $\mathrm{D}$ (Fig. 1). Higher total flows of 11 and $17 \mathrm{~L} \mathrm{~min}{ }^{-1}$ were achieved by appropriate increases of air flow into the inlet rings. As air flowing into both rings A and B and spokes C remained constant, the flow of air through the downstream spokes D was briefly $(\ll<1$ s) interrupted by a short burst of $\mathrm{NO}_{2}$. This was achieved by first trapping $\sim 3 \mathrm{~cm}^{3}$ of $\mathrm{NO}_{2}$ at $\sim 25 \mathrm{psig}$ in a short length of Teflon tubing located between two valves: the first was a simple shut-off valve to the $\mathrm{NO}_{2}$ source tank and the second was a three-way valve that was set to deliver a steady flow of air to the downstream spokes as described above. When this three-way valve was rapidly rotated $90^{\circ}$ and 
back again, a "plug" of $\mathrm{NO}_{2}$ was injected through the down-stream glass spokes $\mathrm{D}$ into the flow tube. In this way, disruptions to the total flow were minimized.

UV/Vis spectrometry (Ocean Optics, HR4000) was used to measure $\mathrm{NO}_{2}$ absorbance at $420.43 \mathrm{~nm}$ as a function of time as the plug of $\mathrm{NO}_{2}$ was sampled by pumping on the downstream side of a $10.0 \mathrm{~cm}$ UV/Vis cell connected to the end of the stainless-steel sampling tube. This wavelength was chosen because there is strong absorbance from $\mathrm{NO}_{2}$ but negligible absorbance (Vandaele et al., 1998) from $\mathrm{N}_{2} \mathrm{O}_{4}$ formed from the equilibrium reaction, $2 \mathrm{NO}_{2} \leftrightarrow \mathrm{N}_{2} \mathrm{O}_{4}$. The software controlling the spectrometer (SpectraSuite) was operated in strip-chart mode with a $150 \mathrm{~ms}$ integration time and an average of three scans. In the strip-chart mode, the time elapsed between the rotation of the valve and the maximum absorbance observed was recorded and averaged over four to seven injections. This average was then plotted for each distance between the spokes and sampling line, $\Delta \mathrm{L}$, and a leastsquares fit to the data (Fig. 3) was obtained. Two standard errors of the time averages were typically $4 \%$, however twice the standard error of the least-square slopes were considerably larger, up to $14 \%$. The slope for each plot equals the inverse of the flow velocity and is the conversion factor that translates $\Delta \mathrm{L}$ distances into residence times. By adjusting the distance between the downstream inlet spokes D and the sampling tube, residence times within the flow tube between 0.2 to 30 seconds could be obtained at total flows from 6 to $17 \mathrm{~L} \mathrm{~min}^{-1}$. This time range is appropriate if the reaction under study stops as gas-phase reactants enter the sampling tube and quickly diffuse to the wall. However, if reaction/particle formation continued within the sampling tube and line and SMPS, then up to an additional 2 seconds elapse, and the residence time range is from 2.2 to 32 seconds. The data in Fig. 3 were obtained at room temperature, $23 \pm 1^{\circ} \mathrm{C}$. Additional residence time measurements were also made at $55^{\circ}$ and $70^{\circ} \mathrm{C}$ and the results at all temperatures are summarized in Table 1 . Considering the 
large standard error of the slopes as well as the existence of a small turbulent region at the spokes (see section 4.1), there is no significant temperature dependence on flow velocity at any given total flow.

\subsection{Kinetics of NO Oxidation by $\mathrm{O}_{2}$}

In order to further test the flow dynamics and in particular the relationship between distance along the flow tube and reaction time, a series of experiments were conducted to measure the rate constant, $\mathrm{k}_{1}$, for the gas-phase reaction:

$$
2 \mathrm{NO}+\mathrm{O}_{2} \stackrel{\mathrm{k}_{1}}{\longrightarrow} 2 \mathrm{NO}_{2}
$$

Selected flows of either pure NO (Praxair, 99.5\%), or a mixture of NO and nitrogen were introduced through the spokes D, nitrogen (Praxair, 99.9999\%) was added through spokes $\mathrm{C}\left(2.0 \mathrm{~L} \mathrm{~min}^{-1}\right)$ and additional nitrogen was added at various flows through the inlet ring $\mathrm{B}\left(0.6\right.$ to $\left.1.7 \mathrm{~L} \mathrm{~min}^{-1}\right)$ and oxygen (Praxair, 99.999\%) at various flows (2.2 to $15 \mathrm{~L} \mathrm{~min}^{-1}$ ) through the inlet ring A. For each chosen $\Delta \mathrm{L}$, corresponding to a known residence time, and for initial conditions where $\left[\mathrm{O}_{2}\right]_{0} / 2[\mathrm{NO}]_{0}>12$, samples were continuously pumped at $1.5 \mathrm{~L} \mathrm{~min}^{-1}$ through the UV/Vis cell and the absorbance due to $\mathrm{NO}_{2}$ was monitored at $420.43 \mathrm{~nm}$. Data were acquired using SpectraSuite software (Ocean Optics) operated in scanning mode with one second integration time with spectra averaged every ten scans. Ten such scans were recorded for each $\Delta \mathrm{L}$ and set of initial $\mathrm{NO}$ and $\mathrm{O}_{2}$ concentrations and the average absorbance at $420.43 \mathrm{~nm}$ was determined. A calibration plot (obtained separately by flowing known concentrations of pure $\mathrm{NO}_{2}$ through the cell and recording the absorbance) was then used to determine the corresponding $\mathrm{NO}_{2}$ concentration at time $t,\left[\mathrm{NO}_{2}\right]_{t}$. Initial concentrations of nitric oxide and of oxygen, $[\mathrm{NO}]_{0}$ and $\left[\mathrm{O}_{2}\right]_{0}$, were chosen such that, for each set of measurements, $\left[\mathrm{O}_{2}\right]_{0}$ was at least in a 
12-fold excess of $2[\mathrm{NO}]_{0}$ and pseudo second-order kinetics applied. Under these conditions, at time $t$, the reciprocal of NO concentration obeys the relationship, $[\mathrm{NO}]_{t}^{-1}=2 \mathrm{k}_{1}\left[\mathrm{O}_{2}\right]_{0} \mathrm{t}+[\mathrm{NO}]_{0}^{-1}$. Thus, a plot of $[\mathrm{NO}]_{t}^{-1}$ vs. time should be linear with a slope equal to $2 \mathrm{k}_{1}\left[\mathrm{O}_{2}\right]_{0}$.

As noted, $\mathrm{N}_{2} \mathrm{O}_{4}$ does not contribute to the recorded absorbance, but it is present at equilibrium and must be considered to accurately determine $[\mathrm{NO}]_{\mathrm{t}}$ as a function of residence time. To do so, its concentration was calculated from $\left[\mathrm{N}_{2} \mathrm{O}_{4}\right]_{\mathrm{t}}=\mathrm{K}_{\mathrm{eq}}\left[\mathrm{NO}_{2}\right]_{t}^{2}$, where $\mathrm{K}_{\mathrm{eq}}=3.26 \times 10^{-19} \mathrm{~cm}^{3}$ molecule ${ }^{-1}$ at $296 \mathrm{~K}$ (Sander et al., 2011). Thus, $[\mathrm{NO}]_{\mathrm{t}}=[\mathrm{NO}]_{0}-\left[\mathrm{NO}_{2}\right]_{t}-2\left[\mathrm{~N}_{2} \mathrm{O}_{4}\right]_{\mathrm{t}}$. An example of a typical plot is shown in Figure 4. A total of 11 such plots were obtained and the ratios of slope $/ 2\left[\mathrm{O}_{2}\right]_{0}$, which gives the experimental termolecular rate constant, $\mathrm{k}_{1}$, were calculated.

In contrast to carrying out kinetic studies under pseudo-first order conditions where only relative rates of loss need to be measured, absolute concentrations were required in this case. In addition, the range of initial $[\mathrm{NO}]_{0}$ values that could be used was limited, with a $62 \%$ increase from the minimum to maximum in order to maintain $\left[\mathrm{O}_{2}\right]_{0} / 2[\mathrm{NO}]_{0}>12$. Moreover, even though the reaction time was varied by a factor of seven, the corresponding range of measured absorbance of $\mathrm{NO}_{2}$ at $420.43 \mathrm{~nm}$ (which ultimately determined $[\mathrm{NO}]_{\mathrm{t}}$ ) varied by no more than $18 \%$ as reaction times were changed. Despite these challenges, and although the individual results show considerable scatter as seen in Table 2, excellent agreement with literature values of the rate constant was obtained.

Table 2 summarizes initial reactant concentrations, the values derived for $\mathrm{k}_{1}$, and the standard deviations, $\sigma$. The latter was estimated from the least squares standard deviation for the slope of each $[N O]_{t}^{-1}$ vs. reaction-time plot and the estimated error in the initial oxygen concentration as determined 
from the flow of oxygen and total flow. The value of $\mathrm{k}_{1}$ reported here is a weighted average (Pugh \& Winslow, 1966) where the weight assigned to each value of $\mathrm{k}_{1}$ is $w=1 / \sigma^{2}$. The value obtained from this system at $23^{\circ} \mathrm{C}$ is $(2.0 \pm 0.2) \times 10^{-38} \mathrm{~cm}^{6}$ molecules $\mathrm{s}^{-1}( \pm \sigma)$ and is in excellent agreement with the recommended value of $2.0 \times 10^{-38} \mathrm{~cm}^{6}$ molecules $\mathrm{s}^{-2}$ (Atkinson et al., 2004).

These measurements were repeated with both the flow tube and gases heated with a re-circulating bath to either $50^{\circ}$ or $70^{\circ} \mathrm{C}$ as described previously. In these latter cases the calculated weighted-averaged rate constants and deviations were measured to be $(1.8 \pm 0.6) \times 10^{-38}$ at $50^{\circ} \mathrm{C}$ and $(1.6 \pm 0.6) \times 10^{-38}$ at $70^{\circ} \mathrm{C}$, in units of $\mathrm{cm}^{6}$ molecules $\mathrm{s}^{-1}$, and are also in good agreement with literature values (Table 3).

\subsection{Particle Formation}

Prior experiments in this lab reported new particle formation from the reaction of gas-phase MSA with either TMA or dimethylamine (DMA, $\left(\mathrm{CH}_{3}\right)_{2} \mathrm{NH}$ ) in the presence of water vapor (Dawson et al., 2012). Particle measurements using our large-volume, slow-flow aerosol reactor (Ezell et al., 2010) were made after 4 minutes (the shortest experimentally accessible reaction time) and showed a complex dependence on relative humidity $(\mathrm{RH})$. These results were quantitatively reproduced by the semi-empirical kinetics model discussed in detail elsewhere (Dawson et al., 2012). However, at 4 min reaction time, new particle formation had ceased and significant amounts of particle growth had already occurred, with the geometric mean diameters typically being tens of nanometers.

In order to demonstrate the capabilities of the new fast-flow reactor for probing the chemistry closer to the time of formation of new particles, some experiments were carried out on the MSA reaction with TMA dry and in the presence of water vapor corresponding to 55\% RH. In these experiments, gas 
phase MSA was generated by flowing clean air over traps containing pure liquid MSA (Fluka, $\geq 99.0 \%$ ) into the inlet spokes $\mathrm{C}$, while TMA was added as a mixture in $\mathrm{N}_{2}$ (AirGas, $1.0 \mathrm{ppm}$ ) through the inlet spokes D. The bulk of gas flow into the system was provided by clean dry air flowing directly into fixed inlet rings $\mathrm{A}$ and $\mathrm{B}$, where for humidified air a portion of the flow was passed first through a water bubbler. Particle distributions were obtained by sampling from the stainless steel sampling line with a scanning mobility particle sizer (TSI) (model 3080 classifier, model 3085 nanoDMA and model $3776 \mathrm{CPC}$ ) using $15.0 \mathrm{~L} \mathrm{~min}^{-1}$ sheath flow rate and sample rate of $1.5 \mathrm{~L} \mathrm{~min}^{-1}$. MSA in the inlet flow was measured by collection on a $0.45 \mu \mathrm{m}$ Durapore filter (Millex-HV), extraction in water and analysis by UPLC-MS (Waters Micromass QTOF2). TMA was measured by collection on a weak cation exchange resin followed by extraction with dilute oxalic acid solution and analysis using ion chromatography as described elsewhere (Dawson et al., 2014). The movable sampling tube was adjusted to vary reaction times within the flow tube between 0.3 to 5.9 seconds at a total flow of $17 \mathrm{~L}$ $\min ^{-1}$.

MSA forms hydrates with water (Wyslouzil et al., 1991) and at 55\% RH, there is a distribution of complexes with 0-3 water molecules, with $\sim 75 \%$ of the complexes having one or two waters:

$$
\mathrm{MSA}+y \mathrm{H}_{2} \mathrm{O} \rightarrow \mathrm{MSA} \bullet\left(\mathrm{H}_{2} \mathrm{O}\right)_{y}
$$

As reported in earlier work (Dawson, et al., 2012), MSA hydrates have been proposed to be the initial reactant with the amine:

$$
\mathrm{MSA} \cdot\left(\mathrm{H}_{2} \mathrm{O}\right)_{y}+z \mathrm{TMA} \rightarrow \mathrm{MSA} \bullet\left(\mathrm{H}_{2} \mathrm{O}\right)_{y}(\mathrm{TMA})_{z}
$$

It is expected that the initial acid-base reaction is diffusion controlled (Ortega et al., 2012). The rate constant for MSA $\bullet\left(\mathrm{H}_{2} \mathrm{O}\right)+$ TMA was calculated to be $1.3 \times 10^{-9} \mathrm{~cm}^{3}$ molecule $\mathrm{s}^{-1}$ assuming no steric 
hindrance and zero activation energy (Dawson et al.,2012). In that case, 90\% of the limiting reagent has reacted in $5 \mathrm{~ms}$ at $15 \mathrm{ppb}$ excess reagent, indicating that the initial formation of clusters from MSA hydrates and TMA is complete in the flow tube prior to reaching the sampling line. Given our lower limit of $2.5 \mathrm{~nm}$ for particle detection, the initial clusters will be too small to detect. It is only those that have grown to diameters $>2.5 \mathrm{~nm}$ that are measured. This growth will involve collision of clusters with each other as well as condensation of MSA, TMA or water on the clusters:

$$
\begin{aligned}
& 2 \mathrm{MSA}^{\circ}\left(\mathrm{H}_{2} \mathrm{O}\right)_{y}(\mathrm{TMA})_{z} \rightarrow(\mathrm{MSA})_{2} \cdot\left(\mathrm{H}_{2} \mathrm{O}\right)_{2 y}(\mathrm{TMA})_{2 z} \\
& \mathrm{MSA}_{x}\left(\mathrm{H}_{2} \mathrm{O}\right)_{y}(\mathrm{TMA})_{z}+a \mathrm{MSA} \cdot\left(\mathrm{H}_{2} \mathrm{O}\right)_{y} \rightarrow(\mathrm{MSA})_{x+a}\left(\mathrm{H}_{2} \mathrm{O}\right)_{y+a y}(\mathrm{TMA})_{z} \\
& \mathrm{MSA}_{x}\left(\mathrm{H}_{2} \mathrm{O}\right)_{y}(\mathrm{TMA})_{z}+b \mathrm{TMA} \rightarrow \mathrm{MSA}_{x}\left(\mathrm{H}_{2} \mathrm{O}\right)_{y}(\mathrm{TMA})_{z+b} \\
& \mathrm{MSA}_{x}\left(\mathrm{H}_{2} \mathrm{O}\right)_{y}(\mathrm{TMA})_{z}+c \mathrm{H}_{2} \mathrm{O} \rightarrow \mathrm{MSA}_{x}\left(\mathrm{H}_{2} \mathrm{O}\right)_{y+c}(\mathrm{TMA})_{z}
\end{aligned}
$$

Figure 5 shows the size distributions of particles from the reaction of 15 ppb MSA with 0.8 ppb TMA at 2.2, 5.0 and $7.8 \mathrm{~s}$ reaction time under dry conditions (Fig. 5a) and at 55\% RH (Fig. 5b). Particles grow more rapidly and to larger sizes in the presence of water vapor. Figure 6 shows the time dependence of the number concentration and geometric mean diameter for the reaction of TMA ( 0.5 or $0.8 \mathrm{ppb}$ ) with excess (15 ppb) MSA without and with added water vapor corresponding to $55 \% \mathrm{RH}$. The time scales in Fig. 5, 6 include the $2 \mathrm{~s}$ taken to travel to and through the scanning mobility particle sizer, which may be an overestimate if the species growing the clusters are removed rapidly on surfaces inside the sampling line (Nishino et al., 2014) and particle formation and growth ceases. Note that there are likely trace amounts of water present even under dry conditions since this is not a high vacuum system. 
In contrast to studies using the large aerosol flow tube where the formation of detectable particles had ceased by the first measurement port (4 minutes reaction time) (Dawson et al., 2012), the number concentration of particles is seen to increase on the much shorter time scale of the current experiments. However, consistent with the earlier experiments on longer time scales, the number concentration is significantly larger in the presence of water vapor (Fig. 6a).

As discussed above, it is likely that the initial acid-base reaction is quite fast so that the $0.5-0.8 \mathrm{ppb}$ TMA will be converted to MSA-hydrate-amine clusters (reaction 3) within 5 ms under these conditions. The initial concentration of clusters generated in the presence of excess MSA is therefore likely of the order of the initial TMA concentration, $\sim 10^{10}$ clusters $\mathrm{cm}^{-3}$. However, these are sufficiently small that they will not be detected until they grow above $2.5 \mathrm{~nm}$. Growth into the detectable range by condensation of TMA on the clusters is unlikely since most of it will have been depleted, leaving MSA and water as the most viable contributors to growth. Once particles of detectable size are formed, they do not grow significantly in the absence of added water vapor, but they do at 55\% RH (Fig. 6b), suggesting that condensational growth of clusters by MSA is favored when water vapor is present and MSA is in excess. Note that the concentration of clusters initially generated will be determined by the limiting reagent, in this case TMA, so that as the TMA concentration increases, so does that of the particles ultimately formed (Fig. 6a). At high relative humidity, the size of particles ultimately formed is anti-correlated with the initial TMA concentration because of the competition between nucleation and condensation for MSA. Under lower TMA concentrations fewer MSA molecules participate in nucleation, forming fewer particles and leaving more gas-phase MSA molecules available, along with water, for growing particles to larger diameters. 
A further advantage of this system is the relatively small wall loss for particles. Pre-formed MSATMA particles were prepared in a separate glass-bulb flow reactor with three inlets and a single outlet. An MSA/air mixture was introduced into the first inlet $\left(0.2 \mathrm{~L} \mathrm{~min}^{-1}\right)$; TMA into the second $(0.05 \mathrm{~L}$ $\left.\min ^{-1}\right)$; and either dry or humidified air into the third $\left(10 \mathrm{~L} \mathrm{~min}^{-1}\right)$. The initial mixing ratios inside the glass reactor were MSA $\sim 2.7 \mathrm{ppb}$ and TMA $0.5 \mathrm{ppb}$. The particle/gas mixture flowed out of the bulb reactor into ring inlet $\mathrm{B}$ of the flow tube through a denuder to remove unreacted MSA and/or TMA. Additional clean air was added through ring inlet A (3.75 L min-1), inlet spokes $\mathrm{C}\left(2.0 \mathrm{~L} \mathrm{~min}^{-1}\right)$ and inlet spokes $\mathrm{D}\left(1.0 \mathrm{~L} \mathrm{~min}^{-1}\right)$ bringing the total flow into the flow tube to $17 \mathrm{~L} \mathrm{~min}^{-1}$. The particle concentration was then followed as a function of residence time within the flow system (Fig. 7). Particle loss was fit with a first-order decay, with the wall loss rate constants being $\mathrm{k}_{\text {wall }}=(8.7 \pm 5.7) \times$ $10^{-3} \mathrm{~s}^{-1}$ under dry conditions and $(7.5 \pm 3.9) \times 10^{-3} \mathrm{~s}^{-1}$ at $52 \% \mathrm{RH}( \pm 1 \sigma)$. These are within $2 \sigma$ of zero, but even at $8.7 \times 10^{-3} \mathrm{~s}^{-1}$, the lifetime of particles with respect to wall loss is $115 \mathrm{~s}$, much longer than the time range for which this aerosol flow system was designed. Wall loss could be larger for particles below $2.5 \mathrm{~nm}$ diameter which could not be measured in these studies.

Detailed studies of the MSA-amine- $\mathrm{H}_{2} \mathrm{O}$ reactions over a wide range of conditions and their interpretation using a comprehensive mechanistic scheme are beyond the scope of the present study. However, the preliminary results in Figure 5 establish that with its shorter reaction times, this small volume flow system can provide insights into new particle formation and growth processes that are not possible for the longer reaction times accessible using the larger aerosol flow system (Dawson et al., 2012; Ezell et al., 2010). It also has the ability to change order of addition for reactants that can help to clarify the individual steps in complex reaction schemes that lead to new particle formation. Additionally, with its multiple inlets, it is 
possible to investigate new particle formation from one process (such as $\mathrm{MSA}$, amine, $\mathrm{H}_{2} \mathrm{O}$ ) and growth from another process such as condensation of low volatility organics.

\section{CONCLUSIONS}

The multiple inlet aerosol flow system described here extends the range of reaction times within the flow tube from 0.3 to 30 seconds and has proved suitable for investigating both gas and particle kinetics. Visualization of gas flow along the full range of sample tube positions combined with calculated characteristic flow parameters such as the Reynolds number indicate laminar flow throughout most of the flow tube. The flow system can be easily disassembled for cleaning, minimizing the presence of trace contaminants that can influence the chemistry. The results of initial studies of the MSA/trimethylamine/water system illustrate its utility in probing the fundamental mechanisms involved in NPFG. Detailed studies of the reactions of variety of amines using this system will be described in future publications.

\section{Acknowledgements}

We are grateful to the Department of Energy (grant \# ER65208) and the National Science Foundation (grant \# 0909227) for support of this work. We thank Jorg Meyer and Lee Moritz for superb technical assistance in designing and fabricating the flow tube system, Metrohm Corp. for providing the ion chromatograph used for amine measurements and John Greaves for the UPLC-MS for MSA measurements. 
Table 1

Residence time measurements at various temperatures and flow rates.

\begin{tabular}{|c|c|c|c|c|c|c|}
\hline \multirow{2}{*}{$\begin{array}{l}\text { Flow rates } \\
\text { Temperature }\end{array}$} & \multicolumn{2}{|c|}{$6 \mathrm{~L} \mathrm{~min}^{-1}$} & \multicolumn{2}{|c|}{$11 \mathrm{~L} \min ^{-1}$} & \multicolumn{2}{|c|}{$17 \mathrm{~L} \min ^{-1}$} \\
\hline & $\begin{array}{c}\text { Average slope } \\
(\mathrm{s} / \mathrm{cm})\end{array}$ & $\begin{array}{l}\text { Flow velocity } \\
(\mathrm{cm} / \mathrm{s})\end{array}$ & $\begin{array}{l}\text { Average slope } \\
\quad(\mathrm{s} / \mathrm{cm})\end{array}$ & $\begin{array}{l}\text { Flow velocity } \\
(\mathrm{cm} / \mathrm{s})\end{array}$ & $\begin{array}{l}\text { Average slope } \\
\text { (s/cm) }\end{array}$ & $\begin{array}{c}\text { Flow velocity } \\
(\mathrm{cm} / \mathrm{s})\end{array}$ \\
\hline $23^{\circ} \mathrm{C}$ & 0.348 & 2.87 & 0.183 & 5.46 & 0.140 & 7.15 \\
\hline $5^{\circ}{ }^{\circ} \mathrm{C}$ & 0.322 & 3.11 & 0.204 & 4.91 & 0.164 & 6.08 \\
\hline $7^{\circ}{ }^{\circ} \mathrm{C}$ & 0.317 & 3.16 & 0.215 & 4.64 & 0.160 & 6.25 \\
\hline
\end{tabular}

Table 2

Summary of kinetics of the oxidation of $\mathrm{NO}$ by $\mathrm{O}_{2}$ at $23^{\circ} \mathrm{C}$.

\begin{tabular}{|c|c|c|c|c|c|}
\hline Experiment & $\begin{array}{l}{\left[\mathrm{O}_{2}\right]_{0}\left(10^{18}\right.} \\
\left.\text { molecules cm } \mathrm{cm}^{-3}\right)\end{array}$ & $\begin{array}{l}{\left[\mathrm{NO}_{0}\left(10^{18}\right.\right.} \\
\left.\text { molecules } \mathrm{cm}^{-3}\right)\end{array}$ & {$\left[\mathrm{O}_{2}\right]_{0} / 2[\mathrm{NO}]_{0}$} & $\begin{array}{l}\text { Slope }\left[\mathrm{NO}_{2}\right]_{\mathrm{t}}^{-1} \text { vs. time }\left(10^{-19}\right. \\
\left.\mathrm{cm}^{3} \text { molecules }^{-1} \mathrm{~s}^{-1}\right)\end{array}$ & $\begin{array}{l}\mathrm{k}_{1}\left(10^{-38} \mathrm{~cm}^{6}\right. \\
\left.\text { molecules }^{-2} \mathrm{~s}^{-1}\right)\end{array}$ \\
\hline 1 & 9.10 & 0.374 & 12 & 2.11 & $1.16 \pm 0.15$ \\
\hline 2 & 14.0 & 0.253 & 28 & 5.92 & $2.12 \pm 0.15$ \\
\hline 3 & 10.8 & 0.337 & 16 & 6.74 & $3.12 \pm 0.16$ \\
\hline 4 & 12.1 & 0.289 & 21 & 11.5 & $4.78 \pm 0.40$ \\
\hline 5 & 15.7 & 0.225 & 35 & 5.68 & $1.81 \pm 0.15$ \\
\hline 6 & 9.53 & 0.370 & 13 & 4.65 & $2.44 \pm 0.11$ \\
\hline 7 & 12.1 & 0.292 & 21 & 6.53 & $2.69 \pm 0.12$ \\
\hline 8 & 17.3 & 0.199 & 44 & 5.62 & $1.62 \pm 0.14$ \\
\hline 9 & 9.49 & 0.372 & 13 & 3.75 & $1.97 \pm 0.08$ \\
\hline 10 & 21.8 & 0.145 & 76 & 7.26 & $1.66 \pm 0.07$ \\
\hline \multirow[t]{2}{*}{11} & 9.47 & 0.378 & 13 & 3.41 & $1.80 \pm 0.07$ \\
\hline & & & & Weighted average $=$ & $2.0 \pm 0.2$ \\
\hline
\end{tabular}


Table 3

Summary of rate constants $\mathrm{k}_{1}$ for the oxidation of $\mathrm{NO}$ by $\mathrm{O}_{2}$ as a function of temperature.

\begin{tabular}{|c|c|c|c|}
\hline \multirow[t]{2}{*}{ Temperature } & \multirow[t]{2}{*}{ Number of experiments } & \multicolumn{2}{|c|}{ Rate constant $\mathrm{k}_{1}\left(10^{-38} \mathrm{~cm}^{6}\right.$ molecule $\left.^{-2} \mathrm{~s}^{-1}\right)$} \\
\hline & & Experimental $^{\mathrm{a}}$ & Recommended $^{\mathrm{b}}$ \\
\hline $23{ }^{\circ} \mathrm{C}$ & 11 & $2.0 \pm 0.2$ & $1.98 \pm 0.45$ \\
\hline $50{ }^{\circ} \mathrm{C}$ & 6 & $1.8 \pm 0.6$ & $1.70 \pm 0.40$ \\
\hline $70{ }^{\circ} \mathrm{C}$ & 7 & $1.6 \pm 0.6$ & $1.55 \pm 0.36$ \\
\hline
\end{tabular}

andicated uncertainty \pm 1 standard deviation

${ }^{\mathrm{b}}$ Indicated uncertainty \pm approximately $95 \%$ confidence limit (Atkinson et al., 2004) 


\section{Figure Captions}

Figure 1 Fast flow reactor schematic.

Figure 2 Snapshot showing $\mathrm{NO}_{2}$ formed from the reaction of $\mathrm{NO}$, entering through inlet spokes $\mathrm{D}$, with $\mathrm{O}_{2}$ in the air flowing from inlet rings $\mathrm{A}$ and $\mathrm{B}$ (not shown) and inlet spokes $\mathrm{C}$.

Figure 3 Room temperature residence time measurements at 6, 11, and $17 \mathrm{~L} \mathrm{~min}^{-1}$. The slopes of these plots are the reciprocals of the average speed of gas/particles through the flow tube. The uncertainty in the plotted points, based on two standard deviations of the averaged elapsed times, is $\pm 4 \%$ and is too small to display at this scale. However, twice the standard error of the slopes was considerably larger, up to $14 \%$.

Figure 4 Plot of $\left[\mathrm{NO}_{\mathrm{t}}^{-1}\right.$ for Experiment 1 (see Table 2). Error bars are $\pm 8 \%$ based on estimates of errors in $[\mathrm{NO}]_{0},\left[\mathrm{NO}_{2}\right]$ and $\left[\mathrm{N}_{2} \mathrm{O}_{4}\right]$. Slope $=2.11 \times 10^{-19} \mathrm{~cm}^{3}$ molecule $\mathrm{s}^{-1}$.

Figure 5 Size distributions of particles measured by SMPS from the reaction of excess MSA (15 ppb) with TMA (0.8 ppb) at different reaction times (a) under dry conditions, and (b) at 55\% RH. Solid lines, $2.2 \mathrm{~s}$; dot lines, $5.0 \mathrm{~s}$; dot-dash lines, $7.8 \mathrm{~s}$.

Figure 6 (a) Number concentration and (b) diameter as a function of time for the reaction of excess MSA (15 ppb) with TMA under dry and humid conditions. Solid lines and filled symbols, 55\% RH; dashed lines and open symbols, dry. Circles, 0.8 ppb TMA; triangles, 0.5 ppb TMA

Figure 7 Measured wall loss of particle under dry and humid conditions. Particles from MSA reacted with TMA were formed in a separate glass bulb, passed through a denuder to remove residual gaseous precursors and then introduced into the flow system from the ring inlets.

$\mathrm{k}_{\mathrm{wall}, \mathrm{dry}}=(8.7 \pm 5.7) \times 10^{-3} \mathrm{~s}^{-1} ; \mathrm{k}_{\mathrm{wall}, \text { wet }}=(7.5 \pm 3.9) \times 10^{-3} \mathrm{~s}^{-1}$ 


\section{References}

Atkinson, R., Baulch, D.L., Cox, R.A., Crowley, J.N., Jr., R.F.H., Hynes, A.G., Jenkin, M.E., Rossi, M.J., \& Troe, J. (2004). Evaluated kinetic and photochemical data for atmospheric chemistry: Volume I - gas phase reactions of Ox, HOx, NOx and SOx species. Atmospheric Chemistry and Physics, 4, 1461-1738.

Belyaev, S.P., \& Levin, L.M. (1974). Techniques for collection of representative aerosol samples. Aerosol Science, 5, 325-338.

Bernard, F., Fedioun, I., Peyroux, F., Quilgars, A., V.Da“ele, \& A.Mellouki. (2012). Thresholds of secondary organic aerosol formation by ozonolysis of monoterpenes measured in a laminar flow aerosol reactor. Journal of Aerosol Science, 43, 14-30.

Chen, M., Titcombe, M., Jiang, J.K., Jen, C., Kuang, C.A., Fischer, M.L., Eisele, F.L., Siepmann, J.I., Hanson, D.R., Zhao, J., \& McMurry, P.H. (2012). Acid-base chemical reaction model for nucleation rates in the polluted atmospheric boundary layer. Proceedings of the National Academy of Sciences of the United States of America, 109, 18713-18718.

Dawson, M.L., Perraud, V., Gomez, A., Arquero, K.D., M. J. Ezell, \& Finlayson-Pitts, B.J. (2014). Measurement of gas-phase ammonia and amines in air by collection onto an ion exchange resin and analysis by ion chromatography. Atmospheric Measurement Technique Discussions, 7, 1573-1602.

Dawson, M.L., Varner, M.E., Perraud, V., Ezell, M.J., Gerber, R.B., \& Finlayson-Pitts, B.J. (2012). Simplified mechanism for new particle formation from methanesulfonic acid, amines and water via experiments and ab initio calculations. Proceedings of the National Academy of Sciences of the United States of America, 109 18719-18724.

Dommen, J., Riccobono, F., Schobesberger, S., Bianchi, F., Scott, C., Ortega, I.K., Rondo, L., Breitenlechner, M., Junninen, H., Donahue, N.M., Kurten, A., Praplan, A., Weingartner, E., Hansel, A., Curtius, J., Kirkby, J., Kulmala, M., Carslaw, K.S., Worsnop, D.R., Baltensperger, U., \& Collaboration, C. (2013). Role of Organics in Particle Nucleation: From the Lab to Global Model. Nucleation and Atmospheric Aerosols, 1527, 330-333.

Donahue, N.M., Robinson, A.L., \& Pandis, S.N. (2009). Atmospheric organic particulate matter: From smoke to secondary organic aerosol. Atmospheric Environment, 43, 94-106.

Ehn, M., Thornton, J.A., Kleist, E., Sipila“, M., Junninen, H., Pullinen, I., Springer, M., Rubach, F., Tillmann, R., Lee, B., Lopez-Hilfiker, F., Andres, S., Acir, I.-H., Rissanen, M., Jokinen, T., Schobesberger, S., Kangasluoma, J., Kontkanen, J., Nieminen, T., Kurten, T., Nielsen, L.B., Jørgensen, S., Kjaergaard, H.G., Canagaratna, M., Maso, M.D., Berndt, T., Petaja, T., AndreasWahner, Kerminen, V.-M., Kulmala, M., Worsnop, D.R., JurgenWildt, \& Mentel, T.F. (2014). A large source of low-volatility secondary organic aerosol. Nature, 506, 476-479.

Ezell, M.J., Johnson, S.N., Yu, Y., Perraud, V., Bruns, E.A., Alexander, M.L., Zelenyuk, A., Dabdub, D., \& Finlayson-Pitts, B.J. (2010). A new aerosol flow system for photochemical and thermal studies of tropospheric aerosols. Aerosol Science and Technology, 44, 329-338.

Finlayson-Pitts, B.J., \& Pitts, J.N., Jr. (2000). Chemistry of the Upper and Lower Atmosphere - Theory, Experiments, and Applications. Academic Press, San Diego.

Hallquist, M., Wenger, J.C., Baltensperger, U., Rudich, Y., Simpson, D., Claeys, M., Dommen, J., Donahue, N.M., George, C., Goldstein, A.H., Hamilton, J.F., Herrmann, H., Hoffmann, T., Iinuma, Y., Jang, M., Jenkin, M.E., Jimenez, J.L., Kiendler-Scharr, A., Maenhaut, W., McFiggans, G., Mentel, T.F., Monod, A., Prevot, A.S.H., Seinfeld, J.H., Surratt, J.D., 
Szmigielski, R., \& Wildt, J. (2009). The formation, properties and impact of secondary organic aerosol: current and emerging issues. Atmospheric Chemistry and Physics, 9, 5155-5236.

Heal, M.R., Kumar, P., \& Harrison, R.M. (2012). Particles, air quality, policy and health. Chemical Society Reviews, 41, 6606-6630.

Hinds, W.C. (1999). Aerosol Technology: Properties, Behavior and Measurement of Airborne Particles. John Wiley \& Sons Inc., New York.

Holman, J.P. (2002). Heat Transfer. McGraw-Hill, New York.

Holzinger, R., Millet, D.B., Williams, B., Lee, A., Kreisberg, N., Hering, S.V., Jimenez, J., Allan, J.D., Worsnop, D.R., \& Goldstein, A.H. (2007). Emission, oxidation, and secondary organic aerosol formation of volatile organic compounds as observed at Chebogue Point, Nova Scotia. Journal of Geophysical Research, 112, Art. No. D10524.

Incropera, F.P., \& DeWitt, D.P. (2002). Fundamentals of Heat and Mass Transfer (5th ed.). Wiley, New York.

IPCC. (2013). Summary for Policymakers in: Climate Change 2013: : The Physical Science Basis, Contribution of Working Group I to the Fifth Assessment Report of the Intergovernmental Panel on Climate Change. In (Edited Editor), Book Summary for Policymakers in: Climate Change 2013: : The Physical Science Basis, Contribution of Working Group I to the Fifth Assessment Report of the Intergovernmental Panel on Climate Change, City.

Khalizov, A.F., Earle, M.E., Johnson, W.J.W., Stubley, G.D., \& Sloan, J.J. (2006a). Development and characterization of a laminar aerosol flow tube. Review of Scientific Instruments, 77.

Khalizov, A.F., Earle, M.E., Johnson, W.J.W., Stubley, G.D., \& Sloan, J.J. (2006b). Modeling of flow dynamics in laminar aerosol flow tubes. Journal of Aerosol Science, 37, 1174-1187.

Kuang, C., McMurry, P.H., McCormick, A.V., \& Eisele, F.L. (2008). Dependence of nucleation rates on sulfuric acid vapor concentration in diverse atmospheric locations. J. Geophys. Res, 113.

Kulmala, M., Kontkanen, J., Junninen, H., Lehtipalo, K., Manninen, H.E., Nieminen, T., Petaja, T., Sipila, M., Schobesberger, S., Rantala, P., Franchin, A., Jokinen, T., Jarvinen, E., Aijala, M., Kangasluoma, J., Hakala, J., Aalto, P.P., Paasonen, P., Mikkila, J., Vanhanen, J., Aalto, J., Hakola, H., Makkonen, U., Ruuskanen, T., Mauldin, R.L., Duplissy, J., Vehkamaki, H., Back, J., Kortelainen, A., Riipinen, I., Kurten, T., Johnston, M.V., Smith, J.N., Ehn, M., Mentel, T.F., Lehtinen, K.E.J., Laaksonen, A., Kerminen, V.M., \& Worsnop, D.R. (2013). Direct Observations of Atmospheric Aerosol Nucleation. Science, 339, 943-946.

Lee, C.T., \& Kamens, R.M. (2005). Particle nucleation from the reaction of $\alpha$-pinene and $\mathrm{O}_{3}$. Atmospheric Environment, 39, 6822-6832.

Matsunaga, A., \& Ziemann, P.J. (2010). Gas-Wall Partitioning of Organic Compounds in a Teflon Film Chamber and Potential Effects on Reaction Product and Aerosol Yield Measurements. Aerosol Science and Technology, 44, 881-892.

Mauderly, J.L., \& Chow, J.C. (2008). Health effects of organic aerosols. Inhalation Toxicology, 20, 257-288.

McMurry, P.H. (1980). Photochemical aerosol formation from $\mathrm{SO}_{2}$-A theoretical analysis of smog chamber data. Journal of Colloid and Interface Science, 78, 513-527.

Nishino, N., Arquero, K.D., Dawson, M.L., \& Finlayson-Pitts, B.J. (2014). Infrared Studies of the Reaction of Methanesulfonic Acid with Trimethylamine on Surfaces. Environmental Science \& Technology, 48, 323-330.

Ortega, I.K., Kupiainen, O., Kurten, T., Olenius, T., Wilkman, O., McGrath, M.J., Loukonen, V., \& Vehkamaki, H. (2012). From quantum chemical formation free energies to evaporation rates. Atmospheric Chemistry and Physics, 12, 225-235. 
Pandis, S.N., \& Seinfeld, J.H. (2006). Atmospheric Chemistry: From Air Pollution to Climate Change. Wiley, Hoboken, N. J. .

Pope III, C.A., \& Dockery, D.W. (2006). Health effects of fine particulate air pollution: Lines that connect. Journal of the Air \& Waste Management Association, 56, 709-742.

Pöschl, U. (2005). Atmospheric aerosols: composition, transformation, climate and health effects. Angewandte Chemie International Edition, 44, 7520-7540.

Pugh, E.M., \& Winslow, G.H. (1966). The Analysis of Physical Measurements. Addison-Wesley.

Riipinen, I., Sihto, S.L., Kulmala, M., Arnold, F., Dal Maso, M., Birmili, W., Saarnio, K., Teinila, K., Kerminen, V.M., Laaksonen, A., \& Lehtinen, K.E.J. (2007). Connections between atmospheric sulphuric acid and new particle formation during QUEST III-IV campaigns in Heidelberg and Hyyti. Atmospheric Chemistry and Physics, 7, 1899-1914.

Sander, S.P., Friedl, R.R., Barker, J.R., Golden, D.M., Kurylo, M.J., Wine, P.H., Abbatt, J.P.D., Burkholder, J.B., Kolb, C.E., Moortgat, G.K., Huie, R.E., \& Orkin, V.L. (2011). Chemical Kinetics and Photochemical Data for Use in Atmospheric Studies. Evaluation Number 17. In (Edited Editor), Book Chemical Kinetics and Photochemical Data for Use in Atmospheric Studies. Evaluation Number 17 (Vol. JPL Publication 10-6). Jet Propulson Laboratory, City.

Seinfeld, J.H., \& Pandis, S.N. (2006). Atmospheric Chemistry and Physics: From Air Pollution to Climate Change. Wiley-Interscience, New York.

Vandaele, A.C., Hermans, C., Simon, P.C., Carleer, M., Colin, R., Fally, S., Merienne, M.F., Jenouvrier, A., \& Coquart, B. (1998). Measurements of the $\mathrm{NO}_{2}$ absorption cross-section from $4200 \mathrm{~cm}^{-1}$ to $1000 \mathrm{~cm}^{-1}(238-1000 \mathrm{~nm})$ at $220 \mathrm{~K}$ and $294 \mathrm{~K}$. Journal of Quantitative Spectroscopy \& Radiative Transfer, 99, 3-5.

Wyslouzil, B.E., Seinfeld, J.H., Flagan, R.C., \& Okuyama, K. (1991). Binary nucleation in acid water systems. 1. Methanesulfonic acid-water. Journal of Chemical Physics, 94, 6827-6841.

Zhang, R.Y., Khalizov, A., Wang, L., Hu, M., \& Xu, W. (2012). Nucleation and Growth of Nanoparticles in the Atmosphere. Chemical Reviews, 112, 1957-2011.

Zhang, X., Cappa, C.D., Jathar, S.H., McVay, R.C., Ensberg, J.J., Kleeman, M.J., \& Seinfeld, J.H. (2014). Influence of vapor wall loss in laboratory chambers on yields of secondary organic aerosol. Proceedings of the National Academy of Sciences of the United States of America, 111, 5802-5807.

Zhao, J., Ortega, J., Chen, M., McMurry, P.H., \& Smith, J.N. (2013). Dependence of particle nucleation and growth on high molecular weight gas phase products during ozonolysis of $\alpha$-pinene. Atmospheric Chemistry and Physics Discussions, 13, 9319-9354.

Zollner, J.H., Glasoe, W.A., Panta, B., Carlson, K.K., McMurry, P.H., \& Hanson, D.R. (2012). Sulfuric acid nucleation: power dependencies, variation with relative humidity, and effect of bases. Atmospheric Chemistry and Physics, 12, 4399-4411. 


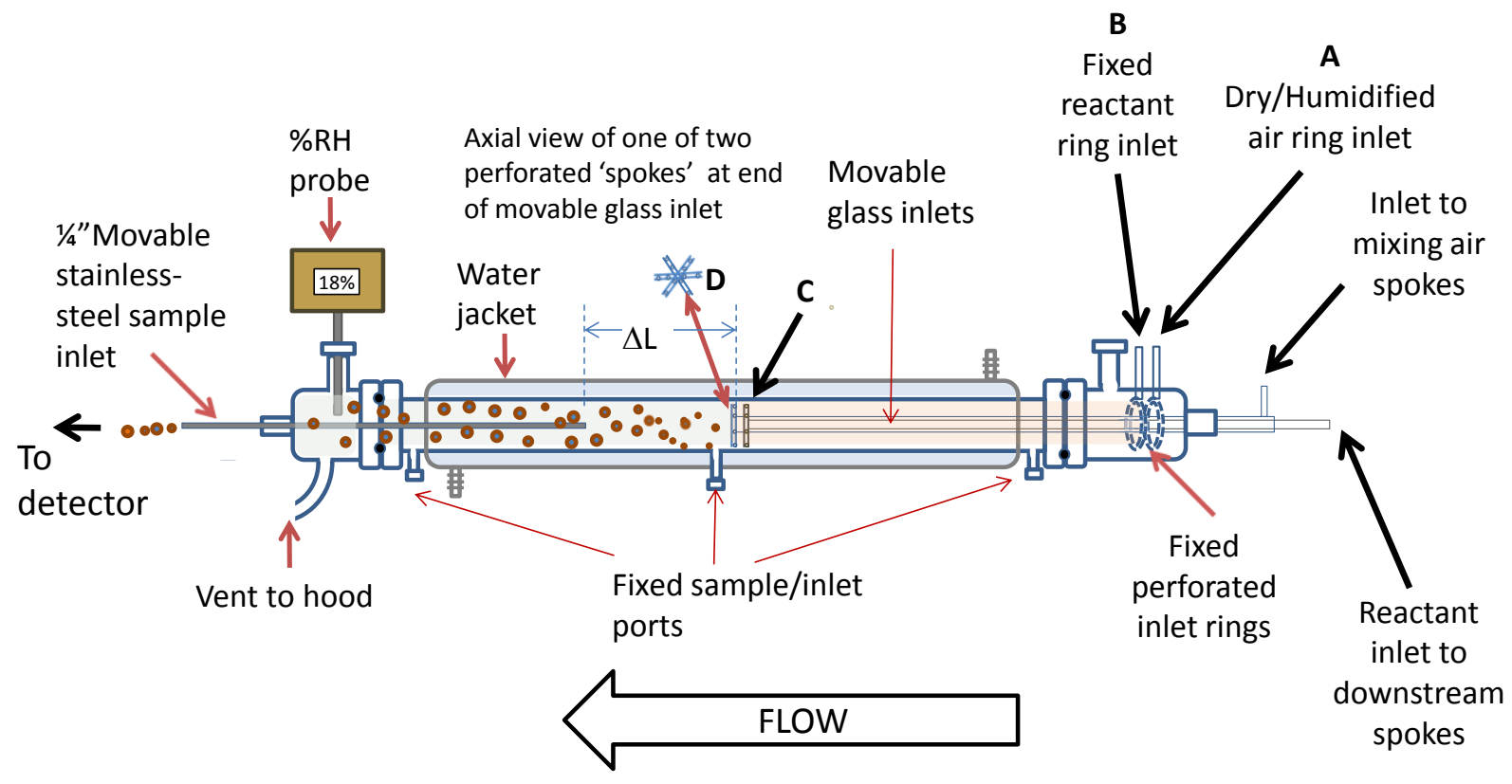

Figure 1. Fast flow reactor schematic 


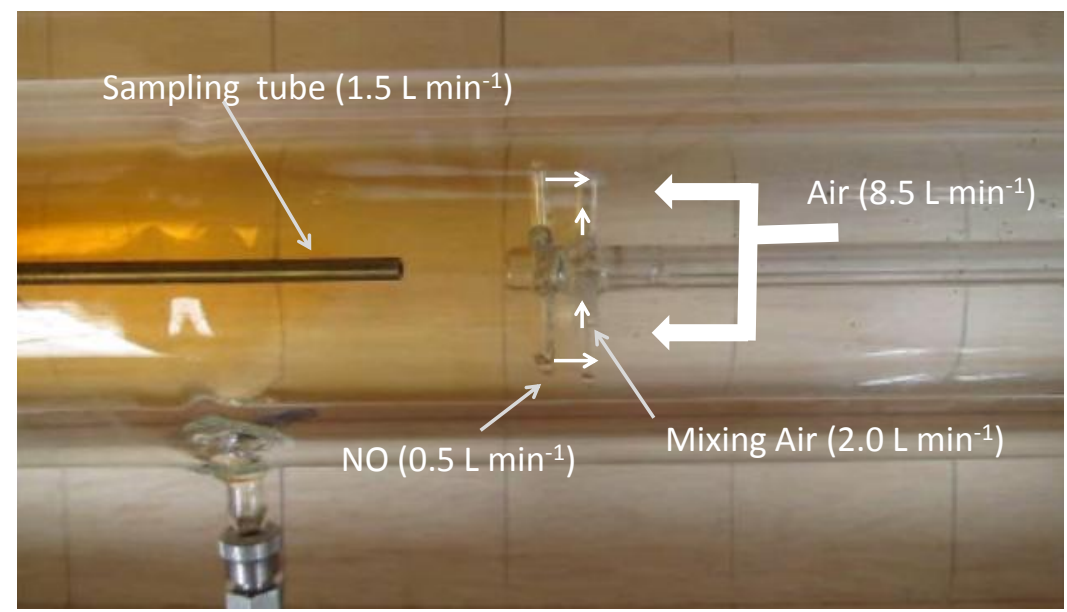

Figure 2. Snapshot showing $\mathrm{NO}_{2}$ formed from the reaction of $\mathrm{NO}$, entering through inlet spokes $\mathrm{D}$, with $\mathrm{O}_{2}$ in the air flowing from inlet rings $\mathrm{A}$ and $\mathrm{B}$ (not shown) and inlet spokes $\mathrm{C}$. 


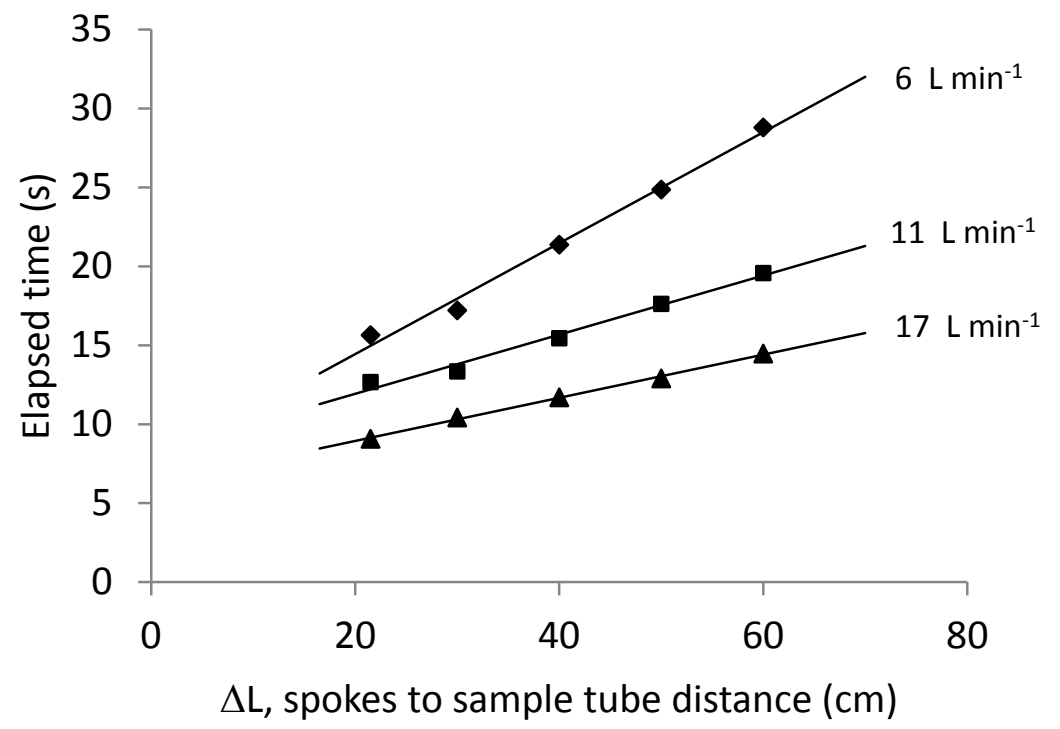

Figure 3. Room temperature residence time measurements at 6,11 , and $17 \mathrm{~L} \mathrm{~min}^{-1}$. The slopes of these plots are the reciprocals of the average speed of gas/particles through the flow tube. The uncertainty in the plotted points, based on two standard deviations of the averaged elapsed times, is $\pm 4 \%$ and is too small to display at this scale. However, twice the standard error of the slopes was considerably larger, up to $14 \%$. 


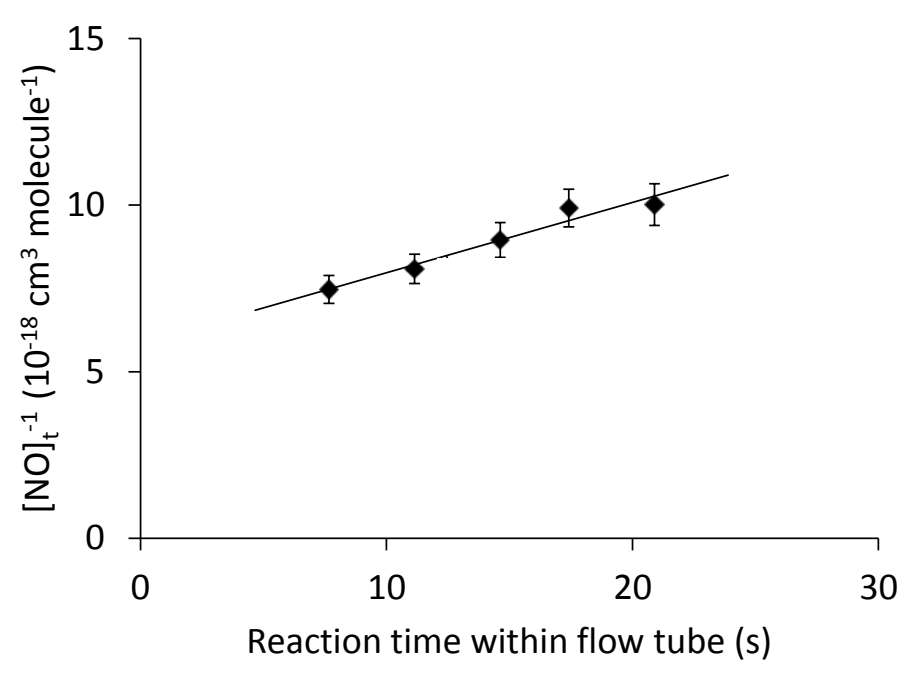

Figure 4. Plot of $[\mathrm{NO}]_{t}^{-1}$ for Experiment 1 (see Table 2). Error bars are $\pm 8 \%$ based on estimates of errors in $[\mathrm{NO}]_{0},\left[\mathrm{NO}_{2}\right]_{\mathrm{t}}$ and $\left[\mathrm{N}_{2} \mathrm{O}_{4}\right]_{\mathrm{t}}$. Slope $=2.11 \times 10^{-19} \mathrm{~cm}^{3}$ molecule ${ }^{-1} \mathrm{~s}^{-1}$. 

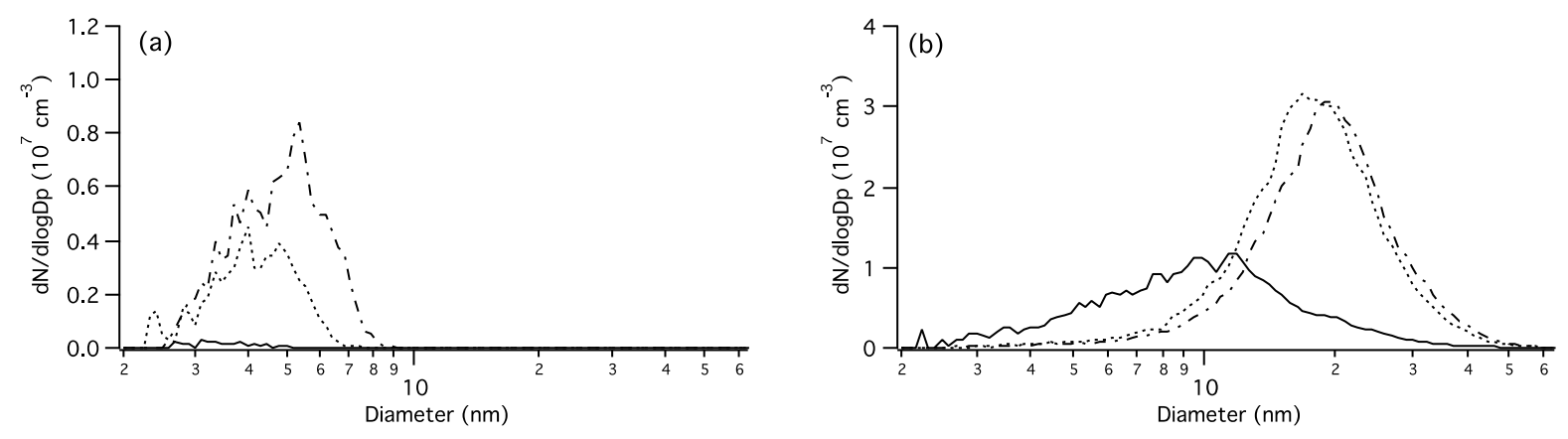

Figure 5. Size distributions of particles measured by SMPS from the reaction of excess MSA (15 ppb) with TMA (0.8 ppb) at different reaction times (a) under dry conditions, and (b) at 55\% RH. Solid lines, $2.2 \mathrm{~s}$; dot lines, $5.0 \mathrm{~s}$; dot-dash lines, $7.8 \mathrm{~s}$. 

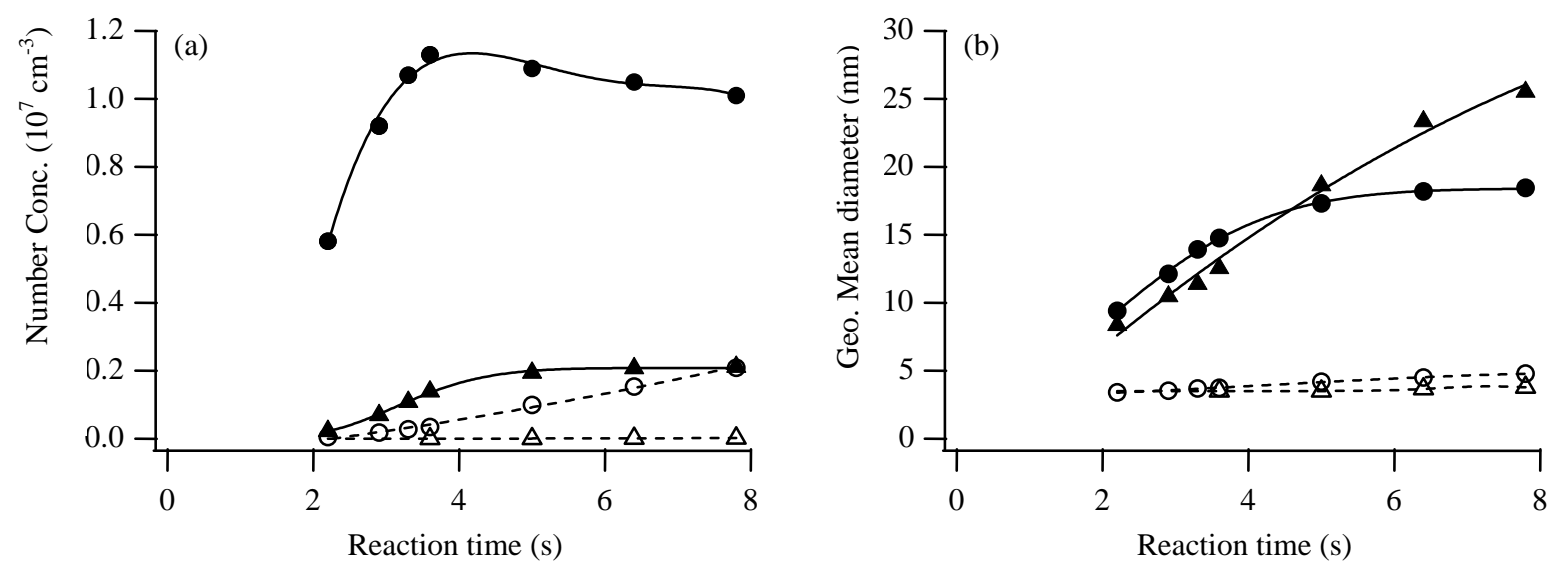

Figure 6. (a) Number concentration and (b) diameter as a function of time for the reaction of excess MSA (15 ppb) with TMA under dry and humid conditions. Solid lines and filled symbols, 55\% RH; dashed lines and open symbols, dry. Circles, 0.8 ppb TMA; triangles, 0.5 ppb TMA 


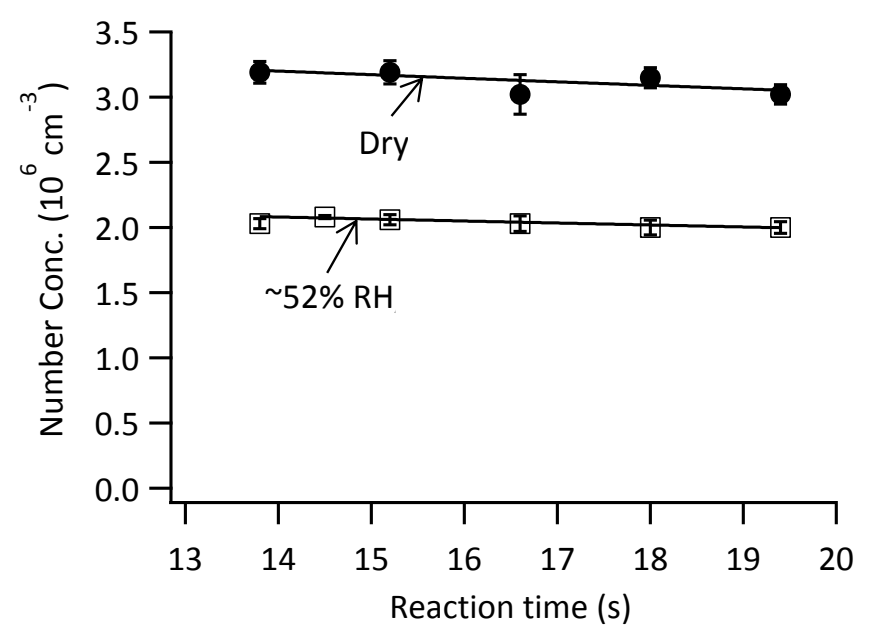

Figure 7. Measured wall loss of particle under dry and humid conditions. Particles from MSA reacted with TMA were formed in a separate glass bulb, passed through a denuder to remove residual gaseous precursors and then introduced into the flow system from the ring inlets.

$\mathrm{k}_{\mathrm{wall}, \text { dry }}=(8.7 \pm 5.7) \times 10^{-3} \mathrm{~s}^{-1} ; \mathrm{k}_{\mathrm{wall}}$, wet $=(7.5 \pm 3.9) \times 10^{-3} \mathrm{~s}^{-1}$ 


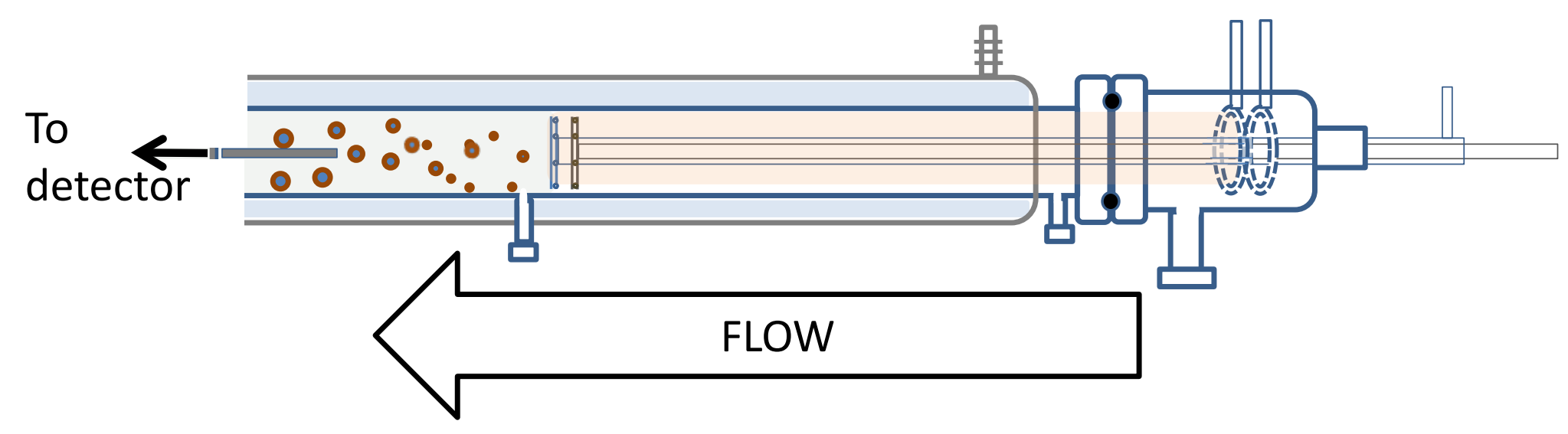

